\title{
DIGITAL COMPETENCE OF A FOREIGN LANGUAGE TEACHER AS A REQUIREMENT OF MODERN SMART EDUCATION
}

\section{Osova Olha ${ }^{1}$}

DOI: https://doi.org/10.30525/978-9934-571-89-3_20

In today's conditions of development of a society which is characterized by globalization and integration processes, an increase in the availability and openness of information resources and means of communication, the rapid development of technological innovations, a broad ground is created for the formation of a new paradigm of education - smart education, which provides the formation of a highly professional, competent teacher of a new generation, capable of professionalpedagogical interaction in the conditions of an updated school.

The concept of smart education is the formation of an intellectual learning environment, ensuring the continuous development of competencies of the participants in the educational process by means of technological innovation. The concept of smart education involves the mobility of learning, the flexibility of the use of didactic material, the diversity of multimedia, the independence of the search and assimilation of information, the introduction of technological innovations in teaching practice, the generation of new ideas, knowledge, creative skills. So, in the concept of smart education in South Korea, seven key skills of a modern specialist are identified:

1) critical thinking and problem-solving; 2) creativity and innovation; 3) cooperation and leadership; 4) intercultural understanding; 5) communication;

\footnotetext{
${ }^{1}$ Kharkiv Humanitarian-Pedagogical Academy, Ukraine
} 
6) literacy in the field of information and communication technologies; 7) career and life skills [1].

It was found that the transition to a new paradigm of "smart" learning leads to new demands for a teacher, who is aware of his social responsibility, constantly cares about personal and professional growth, uses flexible, non-standard approaches to learning and is able to adapt to the rapid living conditions.

In the context of the problem under consideration, we note that the process of informatization of education in Ukraine involves a radical reorganization of the whole system of education, changing the structure and organization of the educational process, the formation of other methodological and didactic foundations, providing a competent approach that requires future teachers not only the system of knowledge, skills, but also key competencies, among which we identify digital competence.

The focus of education on a competent approach, in our opinion, contributes to preservation of the conformity of educational conditions to the needs of the modern smart society caused by dynamic economic development and information "explosion".

American sociologists have developed a model of a "competent worker" in which an attempt to identify a wide range of individual and psychological qualities of a specialist was made, which in our opinion relates appropriately to the requirements of a smart society: discipline, autonomy, communication, commitment to selfdevelopment. In the context of the problem under consideration, special importance is given to the quality, such as the ability of an individual to self-development, which involves the process of independent learning, in which "the person accepts the requirements, transforms them into the level of consciousness, development of abilities, the formation of needs" [2].

As is known, in recent years the newest technologies has brought a lot of the information, communication and technical capabilities to modern education, which makes it possible to use distance-learning programme, digital technologies, the newest information and communication programs for educational purposes. The separating of digital competence as part of the innovative competence of a foreign language teacher is conditioned by the need of a modern smart society in critical and responsible use and interaction of a teacher and digital technologies with the aim of creating favorable conditions for learning a foreign language and participating in the multicultural society. Digital competence is related to the teacher's abilities to use the didactic capabilities of digital technologies in the process of teaching a foreign language, to share experience and information in the global educational environment, to create and distribute digital content, etc.

A modern, competitive, successful foreign language teacher must demonstrate sustainable digital skills that provide interactivity of the process of teaching a foreign language, increase the availability of teaching material, facilitate the development of complex interdisciplinary tasks, increase the students' interest in learning a foreign language and contribute to the development of critical thinking. 
Consequently, in the context of the development of a modern information society, digital competence is one of the new requirements for the training and retraining of pedagogical staff in the field of smart education.

\section{References:}

1. Korsuns'ka L. M. (2013). Koreys'ka kontseptsiya smart-osvity: zahal'ne navchannya, tsyfrovi pidruchnyky i smart-shkoly [Korean concept of smart education: general education, digital textbooks and smart schools]. Osvita ta rozvytok obdarovanoyi osobystosti, № 11, pp. 77-80.

2. Prosser M. (1987). Is Prior Knowledge of Subject Matter More Important to the Development and Use of Meaningful Learning Skill? Programmed Learning and Educational Technology, vol. 24, № 4, pp. 280-285. 